\title{
Czy filozof może być biskupem?
}

O. PROF. DR hAB. JAN ANDRZEJ KŁoczowski OP

Uniwersytet Papieski Jana Pawła II w Krakowie

Filozofowie bywali biskupami, więc widać, że może się to wydarzyć. Niektórzy byli tak wybitnymi filozofami, jak i znakomitymi, czyli świętymi biskupami, wystarczy przywołać postać św. Augustyna. Ale czy dobry filozof może być dobrym biskupem? Takim na pewno był Aurelius Augustinus, który zaczynał jako poszukujący filozof, a po nawróceniu się i objęciu godności biskupiej oddawał się z zapałem pracy duszpasterskiej, choć nie zaniechał pióra.

Inni mieli większe trudności z połączeniem czasu przeznaczonego na filozoficzne dumania z czasem poświęconym trosce o owieczki. I tak po kilku latach pracy w diecezji dominikanin św. Albert powrócił do Kolonii, by pracować w tamtejszym Studium Generale. Ale świętym został, a potomni obdarzyli go tytułem Wielkiego.

\section{Kim jest filozof?}

Mówiąc o filozofie, myślę nie tyle o profesorach filozofii (jakim sam jestem), ile o tych, którzy nie tylko komentowali 
pisma innych myślicieli, lecz także odsłaniali drogę osobistego zmagania sił z rzeczywistością. Istotę uchwycił Platon, a możemy o tym czytać w dialogu Fajdros: „Nazywanie kogoś wiedzącym (sophos) [...] wydaje mi się czymś wielkim i przysługującym tylko Bogu, ale nazywanie miłośnikiem wiedzy (philosophos) może być bardziej dla niego właściwe i (w ogóle) stosowniejsze. [...] Żaden z bogów nie filozofuje, ani pragnie gorąco stać się mądrym. On jest nim już. Nie filozofuje inna osoba, jeśli jest mądra. Również nieświadomi nie filozofują, ani nie pragną gorąco być mądrymi" (278 D).

Podobnie myślał niemiecki myśliciel Lessing, wyrażając swój pogląd w takich mniej więcej słowach: gdyby Bóg, trzymając w swym prawym ręku prawdę, a w lewym zawsze żywe dążenie do prawdy, rzekł do mnie, choćby dodawszy, że zawsze i wiecznie będę się mylił: „Wybieraj!”, przypadłbym Mu z pokorą do lewej ręki i powiedział: „Daj, Ojcze! Czysta prawda jest przecież tylko dla Ciebie samego".

\section{Życiński jako filozof}

Życiński uprawiał filozofię związaną ściśle z refleksją nad naukami przyrodniczymi, ale w typie jego filozofowania zarówno wtedy, gdy pisał, jak i wtedy, gdy wykładał - można dostrzec towarzyszący jego pracy umysłowej rys sokratejski. Polegało to przede wszystkim na żywym kontakcie ze słuchaczami, a może trzeba by powiedzieć - ze słuchaczem, posiadał bowiem niepospolity dar słowa trafiającego 
do jednostki. Nawet w licznym gronie słuchaczy adresatem słów księdza Życińskiego był ten oto człowiek.

Ów rys jego sposobu uprawiania filozofii oddaje poniższy cytat:

Uważam, iż pielęgnowanie sokratejskiego ideału harmonii między teorią i życiem decyduje o celowości i sensie naszych zainteresowań filozoficznych. Dla mnie harmonia życia filozofa z tym, co głosi, jest warunkiem afirmacji jego filozofii. Stąd też sceptycznie odnoszę się do stwierdzeń, że jest rzeczą mało ważną, iż wyznawcy postmodernizmu czy dekonstrukcjonizmu popełniają samobójstwa lub są bohaterami głośnych afer. Dla zweryfikowania swojej teorii fizyk może odwoływać się do danych obserwacyjnych, natomiast miernikiem wartości poglądów filozofa jest jego życie ${ }^{1}$.

Byłoby dużym uproszczeniem sprowadzać tę wypowiedź do zachęty wierności wartościom czy w ogóle do jakiegoś moralizowania. Wymiar sokratejski oznacza także odpowiedzialność w wymiarze poznawczym - istnieje ethos pracy filozoficznej, polegający na uczciwości myślenia. Prawdy się poszukuje, prawdę się odkrywa, ale prawdy się nie posiada. Stąd konieczność zachowania przez filozofa krytycznej czujności.

1 Niewidzialne światło. Z abp. Józefem Życińskim rozmawiają Dorota Zańko i Jarosław Gowin, Kraków 1998, s. 188. 
Życiński jako filozof był tego w pełni świadomy: „Dogmatyzm, w jakiejkolwiek występowałby formie, prowadzi zawsze do uproszczeń i zniekształceń prawdy. Dlatego też wątpliwości w wierze nie są najgorszym zagrożeniem dla życia religijnego. W połączeniu z refleksją i wysiłkiem poszukiwań prowadzą one do oczyszczonej wiary, bardziej subtelnej, rozróżniającej, głębszej. Znacznie bardziej niebezpieczny od wątpliwości jest syty dogmatyzm zadowolonych z siebie osobników, którzy wiedzą wszystko najlepiej"2.

\section{Życiński jako biskup}

Jak to można pogodzić z pełnieniem urzędu biskupiego? Biskup jest człowiekiem wiary, czyli jest mocno utwierdzony w przekonaniu o tym, że Bóg się objawił i dana nam jest wiedza, pewniejsza od naukowych konkluzji, której przedmiotem i celem jest wskazanie drogi pozwalającej człowiekowi osiągnąć cel, jakim jest zbawienie. Ale prawdy wiary mogą być przedstawiane jako abstrakcyjne sformułowania, wyrażone w języku odbiegającym od tego, jakim posługuje się człowiek zanurzony we współczesnym świecie. $Z$ drugiej strony sposobem na przybliżenie teologii - czyli mowy o Bogu - nie może być naiwne uproszczenie i posługiwanie się tak zwanym językiem zwyczajnego człowieka albo - co gorsze - politycznym żargonem. Słowo musi

2 J. Życiński, Głębia bytu, Poznań 1988, s. 19. 
być świadectwem, płynącym z osobistego zakorzenienia się w rzeczywistości duchowej. To ten duchowy wymiar pozwala przemówić w sposób pozwalający na pogłębiony kontakt ze słuchaczem czy czytelnikiem.

Tutaj ważny jest styl, sposób rozumienia - jestem przekonany, że biskup czy - później - arcybiskup Józef Życiński zachował w spełnianiu swego urzędu ten styl, który on sam nazwał sokratejskim.

Karykaturalną namiastkę teologii otrzymujemy wówczas, gdy na marginesie naszych zainteresowań stawiamy osobę Jezusa Chrystusa, rzeczywistość działań Kościoła natomiast zaczynamy opisywać w kategoriach działań lewicy, prawicy, liberałów, fundamentalistów. W perspektywie tej Kościół jawi się wyłącznie jako ludzka instytucja, której działania usiłuje się wyrazić w kategoriach pragmatyki ${ }^{3}$.

Czy filozof - zostając biskupem - staje się funkcjonariuszem kościelnej instytucji? Wnosi jednak - podejmując nowe dla siebie zadania - zdolność i sprawność krytycznego myślenia. Może tę sprawność zgubić, ale nie było to przypadkiem arcybiskupa lubelskiego.

W wywiadzie udzielonym na początku sprawowania tego urzędu powiedział: „Kościół nie jest instytucją dla instytucji czy instytucją podnoszącą wskaźniki zbawiania

3 J. Życiński, Ziarno samotności, Kraków 1997, s. 53. 
świata. Zbawienie dotyczy człowieka, osoby ludzkiej. Jeśli ten człowiek nie traktuje siebie jako skromnego petenta w wielkiej machinie biurokracji kościelnej, odkrywa w Kościele coś z rodziny, coś z atmosfery niewidzialnego Królestwa Bożego, które wzrasta nie przez przeprowadzanie podziału: my, którzy nie życzymy sobie rozmów z biurokratami kościelnymi, i oni - biurokraci. To «my» wyraża się w Ludzie Bożym, reprezentującym różne funkcje i przyjmującym pewien podział charyzmatów"4.

Mam nadzieję, że te krótkie fragmenty z obszernego dorobku naukowego, publicystycznego i duszpasterskiego ks. abp. Józefa Życińskiego dowodzą wyraźnie, że filozof może być biskupem, nawet wybitnym biskupem.

4 J. Życiński, Przeciw obsesji wspótczesności, rozmowa z Andrzejem Nowakiem, „Arcana” nr 37-38 (1992). 